\title{
REDUCTION OF METAL CATIONS CONTENT FROM THE AQUEOUS SOLUTIONS BY SORBENTS
}

\begin{abstract}
IVETA PANDOVA ${ }^{1}$
MIROSLAV RIMAR

${ }^{1}$ Technical University of Kosice, Department of Automotive and Manufacturing Technologies, Faculty of Manufacturing Technologies with a seat in Presov, Slovak Republic

DOI: 10.17973/MMSJ.2021_12_2021044

e-mail: iveta.pandova@tuke.sk

The article presents the results of research on reducing the concentration of heavy metals, such as copper and nickel, on natural zeolite in comparison with synthetic zeolite and chemically treated natural zeolite. The reduction of the content of specific types of heavy metals from aqueous solutions was investigated by the method of sorption kinetics. The results indicate the ability of natural zeolites to compete with synthetic zeolites.
\end{abstract}

KEYWORDS

Zeolites, nickel, cooper, sorption, kinetic, wastewater

\section{INTRODUCTION}

Various human activities, such as ore mining and processing, surface treatment in the engineering industry and various other activities, are sources of toxic metals in water. Metal elements, in trace amounts that are often necessary, are toxic to living organisms in larger quantities. The most toxic are metals that have a high affinity for binding to the reactive groups of enzymes contained in the cells of organisms [Skvarla 2000]. Such elements are, for example, copper and nickel. In the case of copper, especially soluble salts are toxic. Symptoms of poison are stomach problems, with a high content of copper in the blood, liver damage occurs. From a toxic point of view, nickel is classified as a poison. Acute poison results in damage to the digestive tract, blood vessels, kidneys, heart and central nervous system [Abu Al-Rub 2004]. Current European Union legislation effective from 01/01/2004 sets a European limit for $\mathrm{Cu}$ and $\mathrm{Ni}$ ions for wastewater discharges of $1 \mathrm{mgl}^{-1}$. According to BAT limits, it is necessary to minimize the concentrations of heavy metals in litres of wastewater to concentrations of 0.005 to 0.3 milligrams per litre.

Sources of heavy metals are as follows:

- industry - metallurgical, electrical, chemical, textile, tannery, refinery, metallurgical, etc.

- agriculture - fertilizers

- transportation

Suitable techniques for reduction are:

- precipitation / sedimentation (or air flotation) / filtration (or microfiltration or ultrafiltration)

- crystallization

- ion exchange

- nanofiltration (or reverse osmosis).

Recently, more and more sorbents have been used to reduce the concentration of heavy metals.
2 THE SORBENTS UTILIZATION IN THE WASTEWATER PURIFICATION

Heavy metals can be removed in various amounts depending on the dose of sorbent. Thus, for heavy metals, BAT means all of the following:

- segregate waste water containing heavy metal compounds as much as possible

- treat segregated wastewater streams at source before mixing them with other streams and use techniques that allow maximum recovery and, if necessary, allow further removal of heavy metals in the final WWTP as a final treatment step, followed by sludge treatment. Suitable techniques are:

- precipitation / sedimentation (or air flotation) / filtration (or microfiltration or ultrafiltration)

- crystallization

- ion exchange

- nanofiltration (or reverse osmosis).

Based on the latest literature, technology that uses sorption on natural and synthetic sorbents has a dominant position in the water treatment process. It is advantageous if locally available, economically undemanding natural materials and methods are used [Macala 2009, 2017; Pandova 2018, Panda 2014, 2018a,b, 2019; Valicek 2016 and 2017, Balara 2018, Monkova 2013, Gombar 2013, Murcinkova 2013, Bielousova 2017, Flimel 2018, Krehel 2013, Flegner 2019, 2020; Mrkvica 2012, Pollak 2020, Olejarova 2017, Rimar 2016, Zaborowski 2007, Michalik 2014, Straka 2018a,b; Bozek 2021]. Such materials include natural zeolites. Due to their chemical composition, natural zeolites are inorganic, aluminosilicate cations. Zeolite as a carrier matrix is also prerequisite to potentially meet the demanding criteria for the production of new composite materials. Natural zeolites, unlike amorphous organic ions, have a solid skeleton consisting of polyoxides of silicon and aluminium, a sufficiently large adsorption surface, are hydrophilic, polar, microporous, heat and radiation almost resistant, affordable and have lower abrasive properties than activated carbon, which makes them predestines for more suitable hydrodynamic use in practice [Alvarez 2003]. The application possibilities of natural zeolites result from their specific physicochemical properties, which are ion exchange, sorption and derived properties of molecular sieves, dehydration and hydration possibilities, as well as the silicate structure itself and micron dimensions of crystals with very active specific surface area [Van Bekkum 2001, Bailey 1999, Tomeczek 2001]. From the point of view of practical use, clinoptilolite deposits are among the most interesting. Solid state sorption is one of the latest water purification technologies [Belyanovskaya 2020]. The gradual development and improvement of the adsorbent preparation technology has gradually increased their quality, in particular the sorption capacity, the specific surface, the abrasion resistance, the regeneration capacity or the selectivity in relation to certain types of contaminants. The immobilization of heavy metal ions from aqueous solutions on natural zeolitic tuff is a complex process consisting of ion exchange and adsorption, likely to be accompanied by precipitation of metal ion hydroxide complexes on active sites of the particle surface. It is necessary to know the kinetic course of sorption to design the technological arrangement of the purification process.

\section{EXPERIMENTAL}

This paper presents a laboratory experiment to determine the sorption parameters of sorption of copper and nickel cations on natural zeolite - clinoptilolite, which is a low-cost and environmentally friendly sorption material. The natural zeolite 
was compared with the modified zeolite in ammonium form and with the synthetic zeolite - Y-site. The kinetic course of sorption was monitored on natural zeolite clinoptilolite, on its ammonium modification and on synthetic zeolite $Y$-site. For experiments, we used model samples with a content of copper ions $3,0 \mathrm{~g} \cdot \mathrm{dm}-3$ and nickel ions $2.0 \mathrm{~g} \cdot \mathrm{dm}^{-3}$. The experiments were performed at the same time on all three sorbents weighing $50 \mathrm{~g}$, at a temperature of $22^{\circ} \mathrm{C}$. In our experiments, we used the method of static sorption. At regular intervals, during the sorption, a change in the concentration of copper and nickel cations in the solutions was noted until the system reached equilibrium. Analytical determinations of copper and nickel ion concentrations were performed by spectrophotometry. The samples of solution were taken up to equilibrium state at precise time intervals. The cation concentration was determined on an Optima DIGITAL COLORIMETER Model AC 114 photometric analyser (Optima, Tokyo, Japan). It is necessary to know the amount or mass of adsorbed material by weight of the adsorbent, for the qualitative expression of adsorption. The specific adsorption of the adsorbed component is defined by (1) [Korkmaz 2012, Sabova 2010].

$$
a=\frac{c_{0}-c_{r}}{m} \cdot \mathrm{v}
$$

The process of sorption of a chemical substance from solution to solid matter can be expressed as a result of the reversible reaction, sorption and desorption, which achieves the resulting equilibrium between the concentrations of the chemical substance in both phases. This process is generally studied by evaluating the equilibrium concentration of a chemical substance in the sorbent as a function of the total equilibrium concentration in solution at a given temperature. The efficiency of the sorption of soluble matters on the solid matrix to the aqueous solution is most often expressed by the effective distribution coefficient $K_{D}$, which is slope of a straight line of the linear sorption isotherm, and which gives the share of the sorbed amount of the substance in the solid phase $\left(C_{S}\right)$ to its equilibrium concentration in the solution $\left(C_{r}\right)$ during the equilibrium state [Beausse 2004, Delle Site 2001]. This parameter is a quantitative indicator of substance distribution between the solid and liquid phases $K_{D}=c_{s} / c_{r}$. [Korkmaz 2012]. The amount of the sorbed substance per sorbent unit increases linearly with the increasing concentration at low surface coverage, under three assumptions that must be met. The sorption energy must be the same for all sorption sites and it must be independent of the degree of coverage; sorption should take place only at localized sorption sites and without interaction between the sorbed molecules, the sorption capacity being a one-layer coating [Roca 2017, Phan 2006].Assuming that the sorbed substance reaches the sorbent surface by molecular diffusion through a boundary diffusion layer, it is possible to express generally the concentration of the sorbed substance $c$ at a time $t$ by the equation (2) [Pitter 1983].

$$
c=\frac{\lambda c_{r}-\beta e^{\overline{\rho t}}}{\lambda-e^{-\overline{\rho t}}}
$$

where constants $\lambda, \beta, \rho$ are obtained from the measured values of concentration for individual time intervals. We calculate them according to the equations:

$$
\lambda=\frac{c_{0}-\beta}{c_{0}-c_{r}}
$$

$$
\begin{gathered}
\beta=\frac{2 \gamma c_{1}-c_{0}-c_{2}}{\gamma-1}-c_{r} \\
\gamma=\frac{\left(c_{0}-c_{r}\right)\left(c_{2}-c_{r}\right)}{\left(c_{1}-c_{r}\right)^{2}} \\
\overline{\rho=} \frac{1}{t} \ln \frac{\left(c_{0}-c_{r}\right)(c-\beta)}{\left(c_{0}-\beta\right)\left(c-c_{r}\right)}
\end{gathered}
$$

\section{RESULTS AND DISCUTION}

During the sorption process, at regular intervals, a change in the concentration of copper and nickel cations in the solutions was recorded until the system reached the equilibrium state. Copper and nickel ion concentrations were determined photometrically by the calibration curve method. The measured concentration values are located in tables 1 and 3 .

Table 1. Change in the concentration of $\mathrm{Cu}^{+2}$ ions in the solution in time intervals

\begin{tabular}{|l|l|l|l|}
\hline Sorbente & Clinoptilolite & $\begin{array}{l}\mathrm{NH}_{4}^{+} \\
\text {clinoptilolite }\end{array}$ & $\mathrm{Y}$ - site \\
\hline $\begin{array}{l}\text { Time } \\
\text { [minutes] }\end{array}$ & $\mathrm{c}\left[\mathrm{g} \cdot \mathrm{dm}^{/ 3}\right]$ & $\mathrm{c}\left[\mathrm{g} \cdot \mathrm{dm}^{/ 3}\right]$ & $\begin{array}{l}\mathrm{c}[\mathrm{g} \cdot \\
\mathrm{dm} / 3\end{array}$ \\
\hline 0 & 3.00 & 3.00 & 3.00 \\
\hline 60 & 1.51 & 1.50 & 0.82 \\
\hline 120 & 1.12 & 1.13 & 0.75 \\
\hline 180 & 0.90 & 0.88 & 0.66 \\
\hline 240 & 0.52 & 0.50 & 0.00 \\
\hline 300 & 0.52 & 0.50 & 0.00 \\
\hline 360 & 0.53 & & \\
\hline
\end{tabular}

The amount of adsorbed $\mathrm{Cu}^{+2}$ and $\mathrm{Ni}^{+2}$ cations was calculated according to formula (1). The calculated values as well as the equilibrium concentrations are given in tables 2 and 4.

Table 2. Sorbed amounts of $\mathrm{Cu}^{+2}$ on individual sorbents

\begin{tabular}{|l|l|l|l|}
\hline Sorbente & Clinoptilolite & $\mathrm{NH}_{4}{ }^{+}$clinoptilolite & Y-site \\
\hline $\mathrm{c}_{0}\left[\mathrm{~g} \cdot \mathrm{dm}^{-3}\right]$ & 3.00 & 3.00 & 3.00 \\
\hline $\mathrm{c}_{\mathrm{r}}\left[\mathrm{g} \cdot \mathrm{dm}^{3}\right]$ & 0.52 & 0.50 & 0.00 \\
\hline $\mathrm{a}\left[\mathrm{mg} \cdot \mathrm{g}^{-1}\right]$ & 12.40 & 12.51 & 15.00 \\
\hline
\end{tabular}

Table 3. Change in the concentration of $\mathrm{Ni}^{+2}$ ions in the solution in time intervals

\begin{tabular}{|l|l|l|l|}
\hline Sorbente & Clinoptilolite & $\begin{array}{l}\mathrm{NH}_{4}^{+} \\
\text {clinoptilolite }\end{array}$ & Y-site \\
\hline $\begin{array}{l}\text { Time } \\
\text { [minutes] }\end{array}$ & $\mathrm{c}\left[\mathrm{g} \cdot \mathrm{dm}^{-3}\right]$ & $\mathrm{c}\left[\mathrm{g} \cdot \mathrm{dm}^{-3}\right]$ & $\begin{array}{l}\mathrm{c}[\mathrm{g} \cdot \\
\left.\mathrm{dm}^{-3}\right]\end{array}$ \\
\hline 0 & 2.00 & 2.00 & 2.00 \\
\hline 60 & 1.52 & 1.54 & 0.81 \\
\hline 120 & 1.38 & 1.20 & 0.05 \\
\hline 180 & 1.10 & 1.05 & 0.00 \\
\hline 240 & 1.10 & 0.95 & 0.00 \\
\hline 300 & & 0.95 & \\
\hline
\end{tabular}


Table 4. Sorbed amounts of $\mathrm{Ni}^{+2}$ on individual sorbents

\begin{tabular}{|l|l|l|c|}
\hline Sorbente & Clinoptilolite & $\begin{array}{l}\mathrm{NH}_{4}^{+} \\
\text {clinoptilolite }\end{array}$ & Y-site \\
\hline $\mathrm{c}_{0}\left[\mathrm{~g} \cdot \mathrm{dm}^{-3}\right]$ & 2.00 & 2.00 & 2.00 \\
\hline $\mathrm{c}_{\mathrm{r}}\left[\mathrm{g} \cdot \mathrm{dm}^{3}\right]$ & 1.10 & 0.95 & 0.00 \\
\hline $\mathrm{a}\left[\mathrm{mg} \cdot \mathrm{g}^{-1}\right]$ & 4.50 & 5.25 & 10.00 \\
\hline
\end{tabular}

Based on the measurements of the decrease in cation concentrations of both metal elements in the solutions in individual time periods, graphs expressing the kinetic course of sorption were constructed.

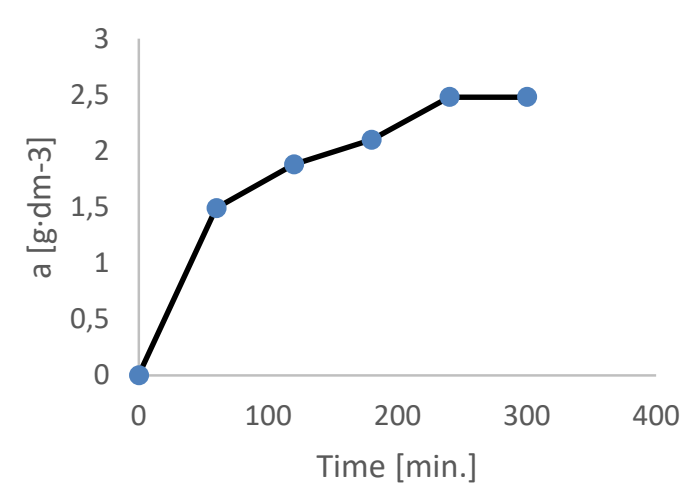

Figure 1. Kinetic course of sorption of $\mathrm{Cu}^{+2}$ cations on clinoptilolite

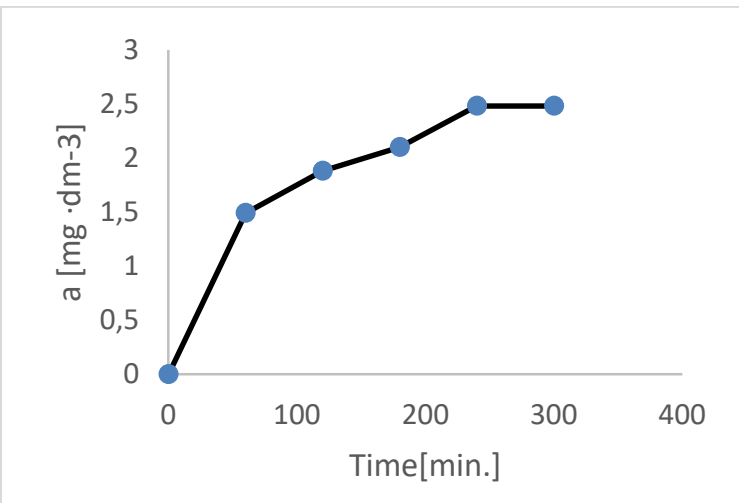

Figure 2. Kinetic course of $\mathrm{Cu}^{+2}$ sorption on $\mathrm{NH}_{4}^{+}$modification of clinoptilolite

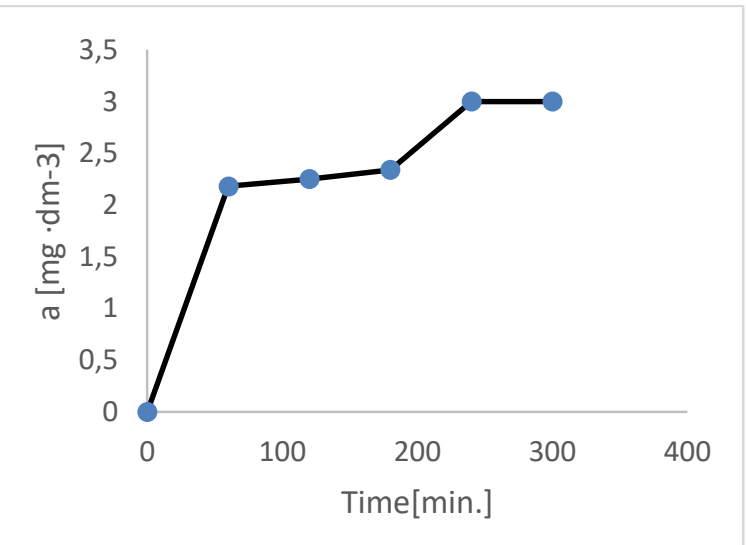

Figure 3. Kinetic course of $\mathrm{Cu}^{+2}$ sorption on $\mathrm{Y}$ - site

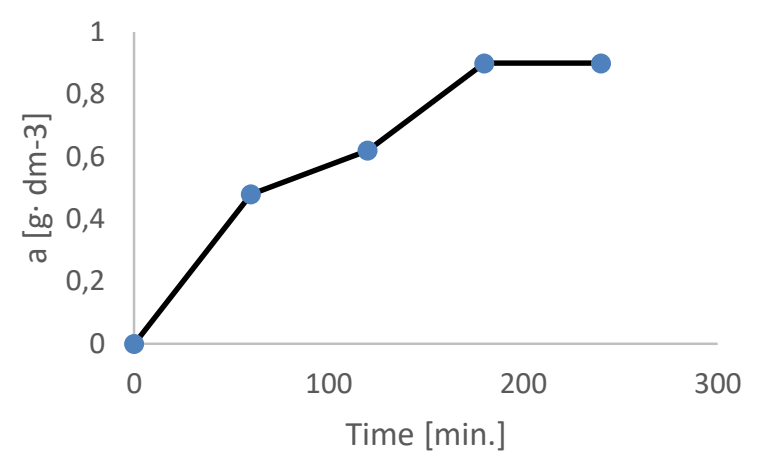

Figure 4. Kinetic course of $\mathrm{Ni}^{+2}$ sorption on clinoptilolite

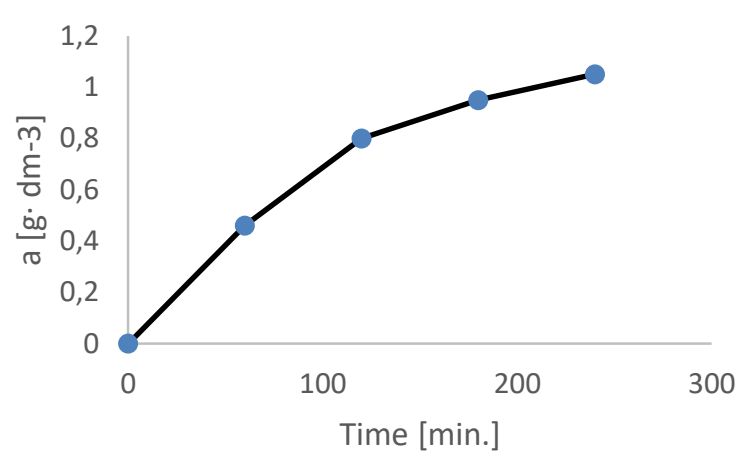

Figure 5. Kinetic course of sorption of $\mathrm{Ni}^{+2}$ on $\mathrm{NH}_{4}{ }^{+}$clinoptilolite

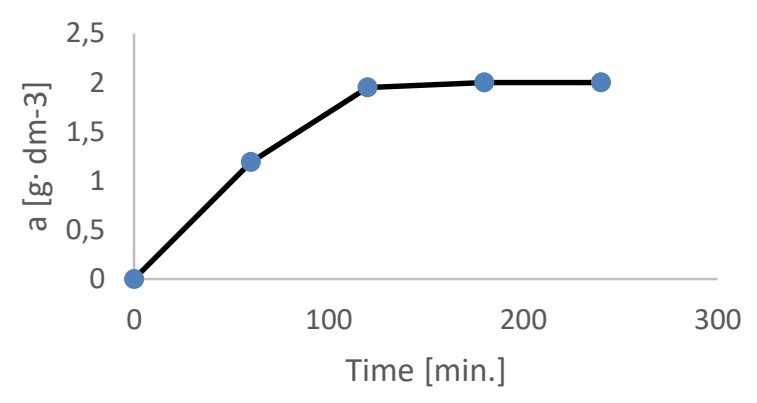

Figure 6. The course of sorption of $\mathrm{Ni}^{+2}$ cations on the $\mathrm{Y}$-site

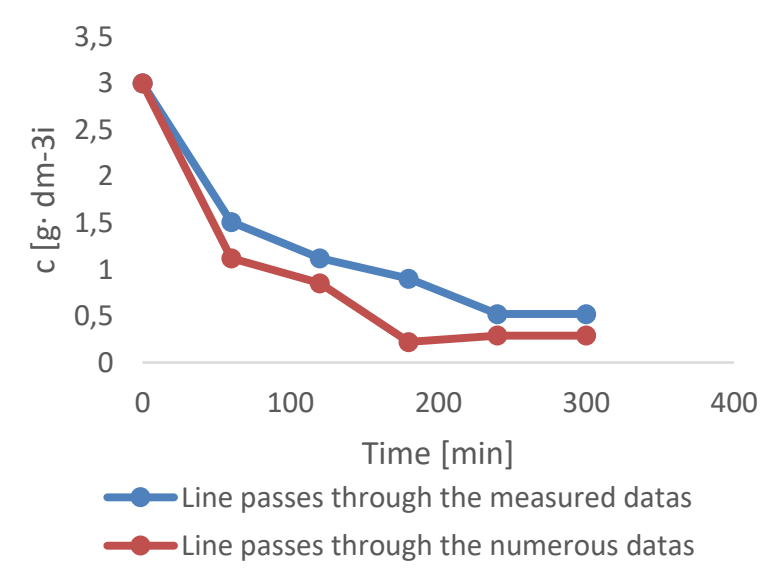

Figure 7. Dependence of the weight concentration c of cupric cations in solution on the time 
Based on the measured values of $\mathrm{Cu}^{+2}$ concentration on natural clinoptilolite, the values of concentration change over time were calculated according to 2 to 5 . From the measured and calculated values, a graph was constructed, which is shown in Figure 7.

Table 5. Temporal change of copper cations and calculated parameters

\begin{tabular}{|c|l|l|l|}
\hline$t$ [min.] & $c_{m}$ & $c_{v}$ & $\sigma\left[\mathrm{min}^{-1}\right]$ \\
\hline 0 & 3 & 3 & \\
\hline 60 & 1.51 & 1.12 & 0.0012 \\
\hline 120 & 1.12 & 0.85 & 0.0013 \\
\hline 180 & 0.90 & 0.22 & 0.0014 \\
\hline 240 & 0.52 & 0.29 & 0.0010 \\
\hline 300 & 0.52 & 0.29 & 0.0010 \\
\hline
\end{tabular}

From the measured concentration values for individual time intervals, the constants were calculated, which were then used for the searched relationship $c=f(t)$. The searched relation $c=f(t)$ is according to the equation (2) with the use of the calculated constants the following:

$$
c_{v}=1,055 \cdot 0,52-0,38 e^{0,0012 \cdot t} / 1,055-e^{-0,0012 \cdot t}
$$

A frequently used quantitative indicator of sorption is the partition coefficient $K_{D}$, which is defined as the ratio of the sorbed amount of the monitored cations in the fat matrix (sorbent) to their concentration in the aqueous solution $c_{r}$ during the equilibrium state. The importance of determining the partition coefficients lies in the fact that they belong to the basic input data in mathematical models of transport of monitored substances in water [Novakova 2016]. According to the formula $\mathrm{K}_{\mathrm{D}}=\mathrm{C}_{\mathrm{S}} / \mathrm{c}_{\mathrm{r}}$, we calculated the partition coefficients. The results are shown in tables 5-7.

Table 6. Values of partition coefficients for $\mathrm{Cu}^{+2}$ sorption

\begin{tabular}{|l|l|l|l|}
\hline Sorbente & Clinoptilolite & $\begin{array}{l}\mathrm{NH}_{4}{ }^{+} \\
\text {clinoptilolite }\end{array}$ & Y-site \\
\hline$C_{r}$ & 0.52 & 0.50 & 0.00 \\
\hline$C_{S}$ & 2.48 & 2.50 & 3.00 \\
\hline$K_{D}$ & 4.76 & 5.00 & 3.00 \\
\hline
\end{tabular}

Table 7. Values of partition coefficients for $\mathrm{Ni}^{+2}$ sorption

\begin{tabular}{|l|l|l|l|}
\hline Sorbente & Clinoptilolite & $\begin{array}{l}\mathrm{NH}_{4}{ }^{+} \\
\text {clinoptilolite }\end{array}$ & Y-site \\
\hline$C_{r}$ & 1.10 & 0.95 & 0.00 \\
\hline$C_{S}$ & 0.90 & 1.05 & 2.00 \\
\hline$K_{D}$ & 0.82 & 1.105 & 2.00 \\
\hline
\end{tabular}

\section{CONCLUSION}

The kinetic course of sorption of the natural zeolite clinoptilolite was compared with the ammonium form and with the synthetic zeolite $y$-site. On synthetic zeolite, sorption proceeded faster and a zero concentration of copper and nickel ions in solution was achieved with $100 \%$ efficiency. On clinoptilolite, $82 \% \mathrm{Cu}^{2+}$ purification efficiency and $45 \% \mathrm{Ni}^{+2}$ efficiency were achieved. Modification of clinoptilolite to the $\mathrm{NH}_{4}{ }^{+}$form caused a slight improvement in potency to $52 \%$ with respect to $\mathrm{Ni}^{+2}$ and to $83 \%$ with respect to $\mathrm{Cu}^{+2}$. From the kinetic dependences, we found that the optimal time to stabilize the equilibrium in the sorption system using natural zeolite is 240 minutes for copper cations and 180 minutes for nickel cations. In the case of natural clinoptilolite, we again observed a slight increase in concentration after 360 minutes, which represents the onset of desorption based on ion exchange. From the measured values of the concentration of $\mathrm{Cu}^{+2}$ cations in the model sample for individual sorption time intervals, constants were calculated, which were subsequently used for the sought relationship $c=f(t)$. It is clear from the figure that the kinetic course of the concentration reduction in the solution was approximately the same with the measured and calculated values. Sorption is a promising and effective technology for removing metal ions from aqueous solutions. This method has several advantages, such as low operating costs, especially when using natural sorbents, high efficiency in removing lower concentrations, ion removal in a relatively short time. The acquired knowledge of basic research on specific natural sorbents can provide important information for technological processes of water treatment.

\section{ACKNOWLEDGMENTS}

This work was supported by the Slovak Research and Development Agency under the contract No. APVV-16-0192. The authors also would like to thank the KEGA grant agency for supporting research work and co-financing the project KEGA 023TUKE-4/2021.

\section{REFERENCES}

[Abu Al-Rub 2004] Abu Al-Rub, F.A., El-Naas, M.H., Benyahia F., Ashour, I. Biosorption of Nickel on Blank Alginate Beads, free and Immobilized Algal cells. Process Biochemistry, 2004, Vol. 39, pp. 1767-1773.

[Alvarez 2003] Alvarez, A., Garcia-Sanches A.G., Querol X. Purification of Metal Electroplating Wastewaters Using Zeolites, Dept. Of Environmental Geochemistry, IRNASA, CSIS. Water Res., 2003, Vol. 37, No. 20, pp. 4855-4862.

[Bailey 1999] Bailey, S.E., et al. A review of potentially low - cost sorbents for heavy metals. Water Research, 1999, Vol. 33, No. 11 , pp. $2469-2479$.

[Balara 2018] Balara, M., Duplakova, D., Matiskova, D. Application of a signal averaging device in robotics. Measurement, 2018, Vol. 115, No. 2, pp. 125-132, Issue 5-8.

[Beausse 2004] Beausse, J. Selected drugs in solid matrices: A review of environmental determination, occurrence and properties of principal substances. Trends Anal. Chem., 2004, Vol. 23, pp. 753-761.

[Belyanovskaya 2020] Belyanovskaya, E., et al. Performance of an Adsorptive Heat-Moisture Regenerator Based on Silica GelSodium Sulphate. Sustainability, 2020, Vol. 12, No. 14, pp. 1-15.

[Bielousova 2017] Bielousova, R. Developing materials for english for specific purposes online course within the blended learning concept. TEM Journal, 2017, Vol. 2017, No. 3, pp. 637642, ISSN 2217-8309.

[Bozek 2021] Bozek, P., Nikitin, Y., Krenicky, T. Methods, Models, Algorithms for Diagnostics of Mechatronic Systems. Studies in Systems, Decision and Control, 2021, Vol. 345, pp. 17-26.

[Delle Site 2001] Delle Site, A. Factors affecting sorption of organic compounds in natural sorbent/water systems and sorption coefficients for selected pollutants. J. Phys. Chem. Ref. Data, 2001, Vol. 30, pp. 187-439.

[Flegner 2019] Flegner, P., Kacur, J., Durdan, M., Laciak, M. Processing a measured vibroacoustic signal for rock type recognition in rotary drilling technology. Measurement, Journal of the Int. Measurement Confeder., 2019, Vol. 134, pp. 451-467. 
[Flegner 2020] Flegner, P., Kacur, J., Durdan, M., Laciak, M. Statistical Process Control Charts Applied to Rock Disintegration Quality Improvement. Applied sciences, 2020, Vol. 10, No. 23, pp. 1-26.

[Flimel 2018] Flimel, M., Duplakova, D. New approaches of heat fluxes determination in the workplace in situ. Flow Measurement and Instrumentation, 2018, Vol. 61, pp. 49-55.

[Gombar 2013] Gombar, M., Vagaska, A., Kmec, J., Michal, P. Microhardness of the Coatings Created by Anodic Oxidation of Aluminium. Applied Mechanics and Materials, 2013, Vol. 308, pp. 95-100.

[Korkmaz 2012] Korkmaz, M., Özmetin, C., Özmetin, E. Copper sorption by clinoptilolite: Equilibrium and thermodynamic investigation. In: 16-th Int. Water Technology Conf., IWTC 16, 2012, Istanbul, Turkey, 2012.

[Krehel 2013] Krehel, R., Straka, L., Krenicky, T. Diagnostics of Production Systems Operation Based on Thermal Processes Evaluation. Appl. Mech. and Mater., 2013, Vol. 308, pp. 121-126.

[Macala 2009] Macala, J., Pandova, I., Panda, A. Clinoptilolite as a mineral usable for cleaning of exhaust gases. Mineral resources management, 2009, Vol. 25, No. 4, pp. 23-32.

[Macala 2017] Macala, J., Pandova, I., Panda, A. Zeolite as a prospective material for the purification of automobile exhaust gases. In: Mineral resources management, 2017, Vol. 33, No. 1, pp. 125-138. ISSN 0860-0953.

[Michalik 2014] Zajac, J., Hatala, M., Mital, D. and Fecova, V. Monitoring surface roughness of thin-walled components from steel C45 machining down and up milling. Measurement, 2014, Vol. 58, pp. 416-428. ISSN 0263-2241.

[Monkova 2013] Monkova, K., Monka, P., Jakubeczyova, D. The research of the high speed steels produced by powder and casting metallurgy from the view of tool cutting life. Applied Mechanics and Materials, 2013, Vol. 302, pp. 269-274.

[Mrkvica 2012] Mrkvica, I., Janos, M., Sysel, P. Cutting efficiency by drilling with tools from different materials. Advanced Materials Research, 2012, Vols. 538-541, pp. 1327-1331.

[Murcinkova 2013] Murcinkova, Z., Krenicky, T. Implementation of virtual instrumentation for multiparametric technical system monitoring. In: SGEM 2013: 13th Int. Multidisciplinary Sci. Geoconf. Vol. 1: 16-22 June, 2013, Albena, Bulgaria. Sofia: STEF92 Technology, 2013, pp. 139-144.

[Novakova 2016] Novakova M., Chmielewska E., Sokolik R. Potential Removal of Nitrate, Sulfate, AR and m-cresol from Waters Using the Inland Natural Resources. Acta Universitatis Matthiae Belii, 2016, Vol. 18, No. 2.

[Olejarova 2017] Olejarova, S., Dobransky, J., Svetlik, J., Pituk, M. Measurements and evaluation of measurements of vibrations in steel milling process. Measurement: Journal of the International Measurement Confederation, 2017, Vol. 106, pp. 18-25.

[Panda 2014] Panda, A., Duplak, J. Comparison of theory and practice in analytical expression of cutting tools durability for potential use at manufacturing of bearings. Applied Mechanics and Materials, 2014, Vol. 616, pp. 300-307. ISSN 1662-7482.

[Panda 2018a] Panda, A., et al. Advantages and effectiveness of the powder metallurgy in manufacturing technologies. Metalurgija, 2018. Vol. 57, No. 4, pp. 353-356. ISSN 0543-5846.

[Panda 2018b] Panda, A., Olejarova, S., Valicek, J., Harnicarova, $M$. Monitoring of the condition of turning machine bearing housing through vibrations. International Journal of Advanced Manufacturing Technology, 2018, Vol. 97, No. 1-4, pp. 401-411.

[Panda 2019] Panda, A., et al. Development of the method for predicting the resource of mechanical systems. International
Journal of Advanced Manufacturing Technology, 2019, Vol. 105, No. 1-4, pp. 1563-1571. ISSN 0268-3768.

[Pandova 2018] Pandova, I., et al. Use of sorption of copper cations by clinoptilolite for wastewater treatment. International Journal of Environmental Research and Public Health, 2018, Vol. 15, No. 7, pp. 1-12. ISSN 1661-7827.

[Phan 2006] Phan, N.T.S., Van Der Sluta, M., Jones C.W. Palladium (II) Catalyst Supported on Polyacetylene Nanoparticles Combining the Advantages of Homogeneous and Heterogeneous Catalysts. Adv. Synth. Catal., 2006, Vol. 348, pp. 609-617.

[Pollak 2020a] Polllak, M., Dobransky, J. Structural design and material cutting using a laser end effector on a robot arm. TEM Journal, 2020, Vol. 9, No. 4, pp. 1455-1459. ISSN 2217-8309.

[Pollak 2020b] Polllak, M., Kocisko, M., Paulisin, D., Baron, P. Measurement of unidirectional pose accuracy and repeatability of the collaborative robot UR5. Advances in Mechanical Engineering, 2020, Vol. 12, No. 12, pp. 1-21.

[Rimar 2016] Rimar, M., Smeringai, P., Fedak M., Kuna S. Technical and software equipment for the real time positioning control system in mechatronic systems with pneumatic artificial muscles. Key Engineering Materials, 2016, Vol. 669, pp. 361-369.

[Roca 2017] Roca Jalil, M.I., Baschini, M., Sapag, K. Removal of Ciprofloxacin from Aqueous Solutions Using Pillared Clays. Materials, 2017, Vol. 10, No. 12, p. 1345.

[Sabova 2010] Sabova L., Chmielewska E., Gaplovska K. Preparation and utilization of combined adsorbents on zeolite base for removal of the oxyanion pollutants from water. Chem. Letters, 2010, Vol. 104, pp. 243-250.

[Skvarla 2000] Skvarla, J. Environmental particles. Kosice, Stroffek, 2000. (in Slovak)

[Straka 2018a] Straka, L., Hasova, S. Optimization of material removal rate and tool wear rate of $\mathrm{Cu}$ electrode in die-sinking EDM of tool steel. Int. J. of Advanced Manufacturing Technology, 2018, Vol. 97, No. 5-8, pp. 2647-2654.

[Straka 2018b] Straka, L., Hasova, S. Prediction of the heataffected zone of tool steel EN X37CrMoV5-1 after die-sinking electrical discharge machining. Journal of engineering manufacture, 2018, Vol. 232, No. 8, pp. 1395-1406.

[Tomeczek 2001] Tomeczek, J., Gil, S. Influence of pressure on the rate of nitric oxide reduction by char. Combustion and Flame, 2001, Vol. 126, Issue 1-2, pp. 1602-1606.

[Valicek 2016] Valicek, J., et al. A new approach for the determination of technological parameters for hydroabrasive cutting of materials. Materialwissenschaft und Werkstofftechnik, 2016, Vol. 47, No. 5-6, pp. 462-471.

[Valicek 2017] Valicek, J., et al. Identification of Upper and Lower Level Yield strength in Materials. Materials, 2017, Vol. 10, No. 9, pp. 1-20. ISSN 1996-1944.

[Van Bekkum 2001] Van Bekkum, H., Flanigen, E.M., Jansen, J.C., (eds.) Introduction to Zeolite science and Practice. Elsevier, Amsterdam, 2001.

[Zaborowski 2007] Zaborowski, T. Ekowytwarzanie. Gorzow, 2007, 100 p.

\section{CONTACTS:}

RNDr. Iveta Pandova, PhD.

Faculty of Manufacturing Technologies of the Technical University of Kosice with a seat in Presov

Bayerova 1, Presov, 080 01, Slovakia

e-mail: iveta.pandova@tuke.sk

\section{SCIENCE JOURNAL I 2021 I DECEMBER}

